\title{
Transition from contractional to transpressive tectonics: evidence from the Feira Nova Region, Rio Capibaribe Domain, Borborema Province, NE Brazil
}

\author{
Valdielly Larisse Silva ${ }^{*}$ (D), Sérgio Pacheco Neves ${ }^{10}$
}

\begin{abstract}
Differences in tectonic style and kinematics in orogenic belts can result from either multiphase or progressive deformation. In eastern Borborema Province, a regional shallow dipping foliation is multiply folded and crosscut by transcurrent shear zones. Here, we investigate if these fabrics resulted from diachronous deformational events or from a single-phase progressive deformation. The study area, the Feira Nova region, mostly comprises metasedimentary rocks from the Surubim Complex, and is bounded by the NE-trending sinistral Gloria do Goitá (GGSZ) and the sinistral contractional Paudalho (PSZ) shear zones, which separate it from Paleoproterozoic basement rocks. Structures can be grouped into a contractional and a transpressional stage, both related to the Brasiliano Orogeny. The contraction-related structures are represented by a gently dipping foliation $\left(\mathrm{S}_{2}\right)$ related to a top-to-the-NW tectonic transport. The contact between the metasedimentary and basement rocks is parallel to $S_{2}$, indicating the fabrics in both lithotypes are of Brasiliano age, with strain localization having produced the PSZ. NW-verging macroscopic folds are consistent with this regime. The following transpression generated steep mylonitic foliation $\left(\mathrm{S}_{3}\right)$ mainly along the GGSZ, and caused refolding. The data here presented are consistent with a progressive deformation history comprising a gradual transition from contraction to transpression.
\end{abstract}

KEYWORDS: Feira Nova Fold Region; transpressional tectonics; magnetometry; Paudalho Shear Zone; Glória do Goitá Shear Zone.

\section{INTRODUCTION}

In protracted tectonic events, the transposition of structures formed during progressive deformation is common (e.g., Gray and Mitra 1999, Baird and Shrady 2011). Strain partitioning into pure and simple shear components in orogenic belts may result in domains with flat-lying fabrics alternating with domains with steep fabrics in transpressive or transtensive regimes (e.g., Tikoff and Greene 1997, Goscombe and Gray 2008). Curvatures or geometric irregularities in transcurrent faults and shear zones may also produce local components of extension or shortening, depending on the kinematics of these structures. Alternatively, transcurrent shear zones may develop later in the orogenic evolution, representing a separate deformation phase from that responsible for the development of a regional flat-lying foliation. In the Borborema Province (Fig. 1A), formed during the Brasiliano Orogeny (650-550 Ma), a flat-lying foliation related to thrusting precedes development of a transcurrent shear zone system (e.g., Guimarães et al. 2004, Neves et al. 2006b, Viegas et al. 2014, Araújo et al. 2014). In the Central Subprovince (Fig. 1B), the latter reflects the accommodation and partitioning of regional

${ }^{1}$ Universidade Federal de Pernambuco - Recife (PE), Brazil. E-mails: vallarisse@gmail.com, sergio.neves@ufpe.br

${ }^{*}$ Corresponding author. strain into E-W-striking dextral and NE-SW striking sinistral conjugate pairs (Vauchez et al. 1995). Folds, which may occur in several phases and produce interference patterns (e.g., Dantas et al. 2003, Neves et al. 2017, 2018), are usually ascribed to transpression during the development of the Borborema shear zone system (e.g., Archanjo et al., 2002, 2013, Santos et al. 2004, Lima et al. 2017). Whether there is partial overlap of the contractional and transpressional regimes or if they resulted from separate deformation phases is a major issue in the tectonic evolution of the region (Neves et al. 2005), and constitutes the aim of the present study.

The structural evolution of the Feira Nova region, located in the Rio Capibaribe Domain, was described here (Fig. 1C). This is a key area to discuss the issues above since previous studies in its southern portion (Lima et al. 2015a, 2015b) documented the existence of contractional and transcurrent shear zones and folds. Lima et al. (2015b) suggested the existence of four deformation phases. $\mathrm{D}_{1}$ would comprise an episode older than $1.7 \mathrm{Ga}$, represented by metamafic dikes crosscutting a supposed early gneissic banding. The following deformation phases $\left(\mathrm{D}_{2}\right.$ and $\left.\mathrm{D}_{3}\right)$ were attributed to the Brasiliano Orogeny, of Neoproterozoic age. $\mathrm{D}_{2}$ would have generated a flat-lying foliation affecting basement orthogneisses and supracrustal rocks and the Paudalho Reverse Shear Zone, with NW tectonic transport. $\mathrm{D}_{3}$ would be of transcurrent nature comprising subvertical mylonitic foliation, represented by the NNE-SSW-striking sinistral Gloria do Goitá Shear Zone and by a synformal-antiformal pair with axial 

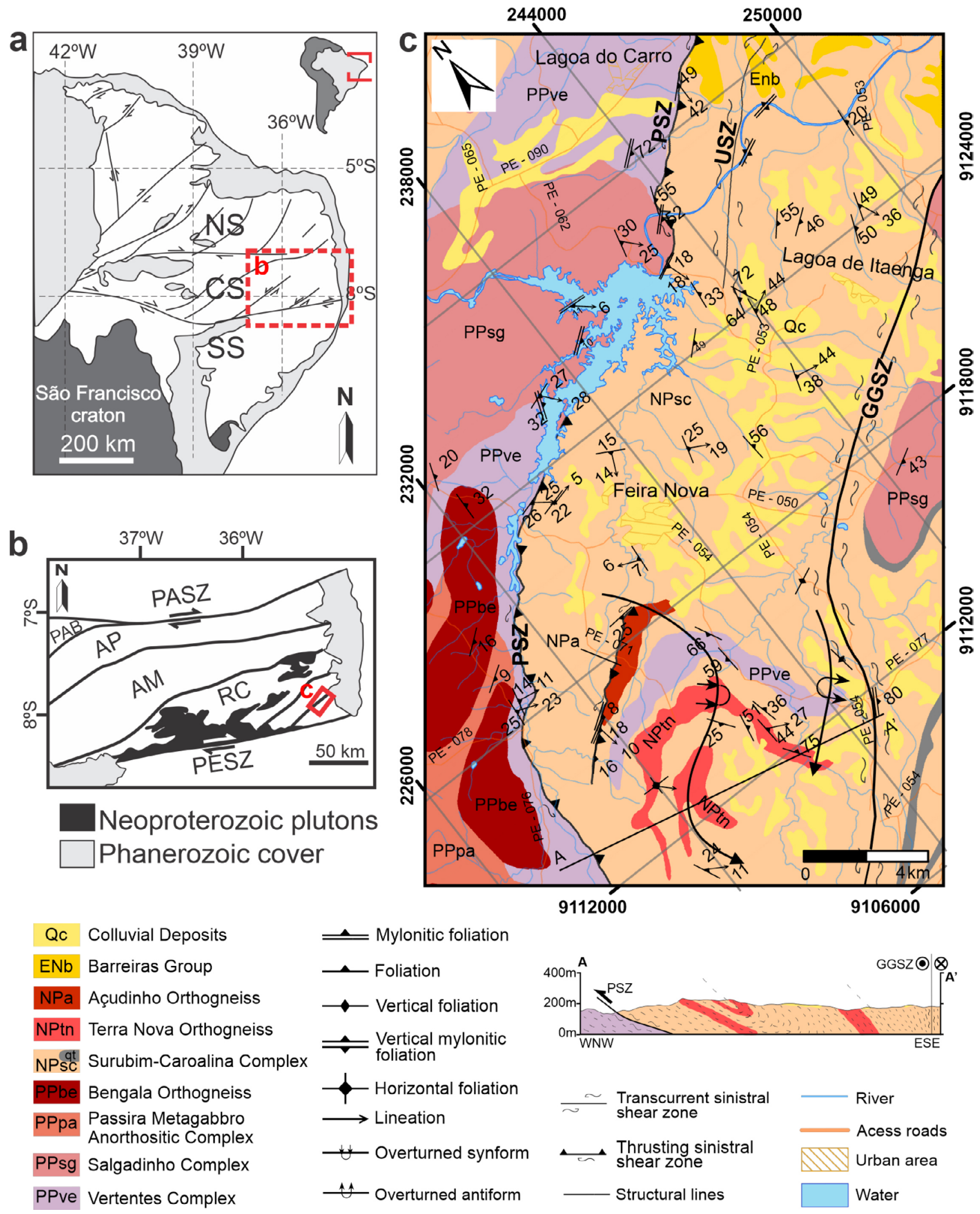

NS: Northern Subprovince; CS: Central Subprovince; SS: Southern Subprovince; AP: Alto Pajeú Domain; AM: Alto Moxotó Domain; RC: Rio Capibaribe Domain; PASZ: Patos Shear Zone; PESZ: Pernambuco Shear Zone

Source: modified from Silva et al. (2020).

Figure 1. Geological map of the Feira Nova region and its location in the Rio Capibaribe Domain and Central Subprovince of the Borborema Province.

traces parallel to this zone. $\mathrm{D}_{4}$ would comprise late tectonic breccias related to younger tectonics. Through additional structural data and geophysical images, we simplify this complex polycyclic model and reinterpret the meaning of Neoproterozoic orthogneisses with intraplate signature present in the region. We characterize the deformation and folding phases of the region and suggest a new working hypothesis in which foliations and folds were produced during a single progressive event that transitioned from a contractional to a transpressive regime. 


\section{GEOLOGICAL SETTING}

\section{Rio Capibaribe Domain}

The Rio Capibaribe Domain is located in the eastern portion of the Central Subprovince of the Borborema Province (Almeida et al. 1981) (Fig. 1B). To the south, the domain is limited by the dextral East Pernambuco Shear Zone, which separates it from the Pernambuco-Alagoas Domain. To the west, it is bounded by the sinistral Congo Shear Zone, which separates it from the Alto Moxotó Domain. A large portion of the Paleoproterozoic basement of the Rio Capibaribe Domain comprises orthogneissic-migmatitic rocks from the Vertentes and Salgadinho complexes (2.18-2.04 Ga) (Neves et al. 2005, 2015). Statherian and Calymmian units (1.7-1.5 Ga) comprise the Serra de Taquaritinga Orthogneisses (Sá et al. 2002) and the Passira Metagabbro-Anorthositic Complex (Accioly et al. 2000). Supracrustal sequences are dominated by paragneiss and micaschist, with subordinate quartzite, marble, and metavolcanic rocks of the Neoproterozoic Surubim Complex (Neves et al. 2006a, 2008). Syn-orogenic plutonism is represented by the Caruaru-Arcoverde granitic batholith (Neves and Mariano 1999) and the Timbaúba and Bom Jardim plutons (Guimarães 1989, Guimarães and Silva Filho 1992).

Neves et al. (2005, 2006a) documented ESE-trending stretching lineations related to the flat-lying foliation with kinematic indicators pointing to top-to-the-NW transport. According to Neves et al. (2005), the main foliation present in the basement and supracrustal rocks of the Rio Capibaribe Domain was affected by three generations of meso- and macroscopic folds:

$\mathrm{F}_{3}$ : south-verging inclined to recumbent, sometimes with axial plane foliation;

$\mathrm{F}_{4}$ : gentle to open NE-SW upright- coeval with transcurrent shear zones;

$\mathrm{F}_{5}$ : NW-SE upright gentle, which bent the axial planes of the previous folds.

These latter generations were considered to result from a component of NE-SW shortening coeval to $\mathrm{F}_{4}$, or the result of late deformation. Intra- and synfolial folds were interpreted as earlier folding episodes $\left(\mathrm{F}_{1}, \mathrm{~F}_{2}\right)$. Phases of similar geometry were described in the Alto Moxotó Domain (Neves et al. 2017,2018 ), but with inverted axial planes between $F_{4}$ and $\mathrm{F}_{5}$, and lack of macroscopic expression for $\mathrm{F}_{3}$.

\section{Feira Nova Region}

The study area comprises the region defined as Feira Nova Fold Belt by Accioly et al. (2003) and Lima et al. (2015a, 2015b), which is located in the eastern Rio Capibaribe Domain (Fig. 1B). It is limited by the Glória do Goitá and Paudalho shear zones, which separate the so-called Carpina and São Lourenço gneissic-migmatitic blocks, respectively. Outcrops are scarce in the region and frequently moderate to highly weathered. Western basement rocks include the Vertentes and Salgadinho complexes (Neves et al.2015) and the Passira Metagabbro-Anorthositic Complex (Accioly et al. 2003), while the supracrustal rocks are dominated by locally migmatized pelitic to semi-pelitic paragneiss and schist, and to a lesser extent, quartzite. Some authors (e.g., Lima et al. 2015a, 2015b) attribute these rocks (or part of their occurrence area) to the Vertentes Complex using the original definition of this unit: sequences of mafic to intermediary metavolcanic rocks and pelitic paragneisses (Santos and Medeiros 1999). Due to the absence of metavolcanic rocks, we consider the metasedimentary rocks to belong to the Surubim Complex (Melo and Siqueira 1971, Neves et al. 2006a).

The most remarkable structure of the region is an overturned synformal-antiformal pair, located in the southern portion of the study area and highlighted by folding of the Açudinho and Terra Nova orthogneisses (Lima et al.2015a, 2015b). The Açudinho Orthogneiss comprises garnet and muscovite-bearing peraluminous leuco-orthogneisses, and the Terra Nova Orthogneiss is a riebeckite-, aegirine-augite-, and magnetite-bearing orthogneiss, both of which were interpreted as folded tabular intrusions (Lima et al. 2015a, 2015b). The Terra Nova Orthogneiss is peralkaline to slightly peraluminous and with a geochemical signature suggesting a post-collisional to an intraplate setting (Lima et al. 2015a). These authors obtained a U-Pb zircon age of $617 \pm 8.8 \mathrm{Ma}$ from a syenitic sample, which they interpreted as suggesting crystallization of the protolith during a transtensional event.

\section{MATERIALS AND METHODS}

Aeromagnetic data used in this work come from the Projeto Aerogeofísico Borda Leste do Planalto da Borborema (code 1079), made by Lasa Engenharia e Prospecções through a partnership between the Geological Service of Brazil (Serviço Geológico do Brasil - CPRM) and the Ministry of Mines and Energy (Ministério de Minas e Energia). The acquisition was made in 2008 and has N-S flight lines, $100 \mathrm{~m}$ of nominal high and $500 \mathrm{~m}$ of spacing. Control lines are E-W and are $5 \mathrm{~km}$ apart. The data obtained were processed by CPRM and by Votorantim Metais Ltda-MMG, including the application of the Reduction to Pole and Vertical Derivative filters to the Total Magnetic Field Anomaly image (Fig. 2).

Some anomalies are too gentle to be noticed on an anomaly map, which requires their amplification by filtering. The Vertical Derivative Anomaly Filter (DZ) (Milligan and Gunn 1997) aims at amplifying, in the vertical direction, the boundaries of anomaly sources and the ones related to faults and other shallow features, being largely used in geological mapping to identify structural features. The Reduction to Pole filter (Baranov and Naudy 1964), in turn, approximately reallocates the anomalies over their sources, converting bipolar asymmetrical anomalies into monopolar symmetrical ones, which are usually simpler and easier to interpret. The application of this filter commonly produces instabilities at low latitude regions, but the results for the study area are satisfactory.

In terms of structural geology, we integrate field observations and mapping features from the existing literature and newly collected data (foliation, lineation, and folding axes), as well as additional macro-, meso-, and microstructural observations. 

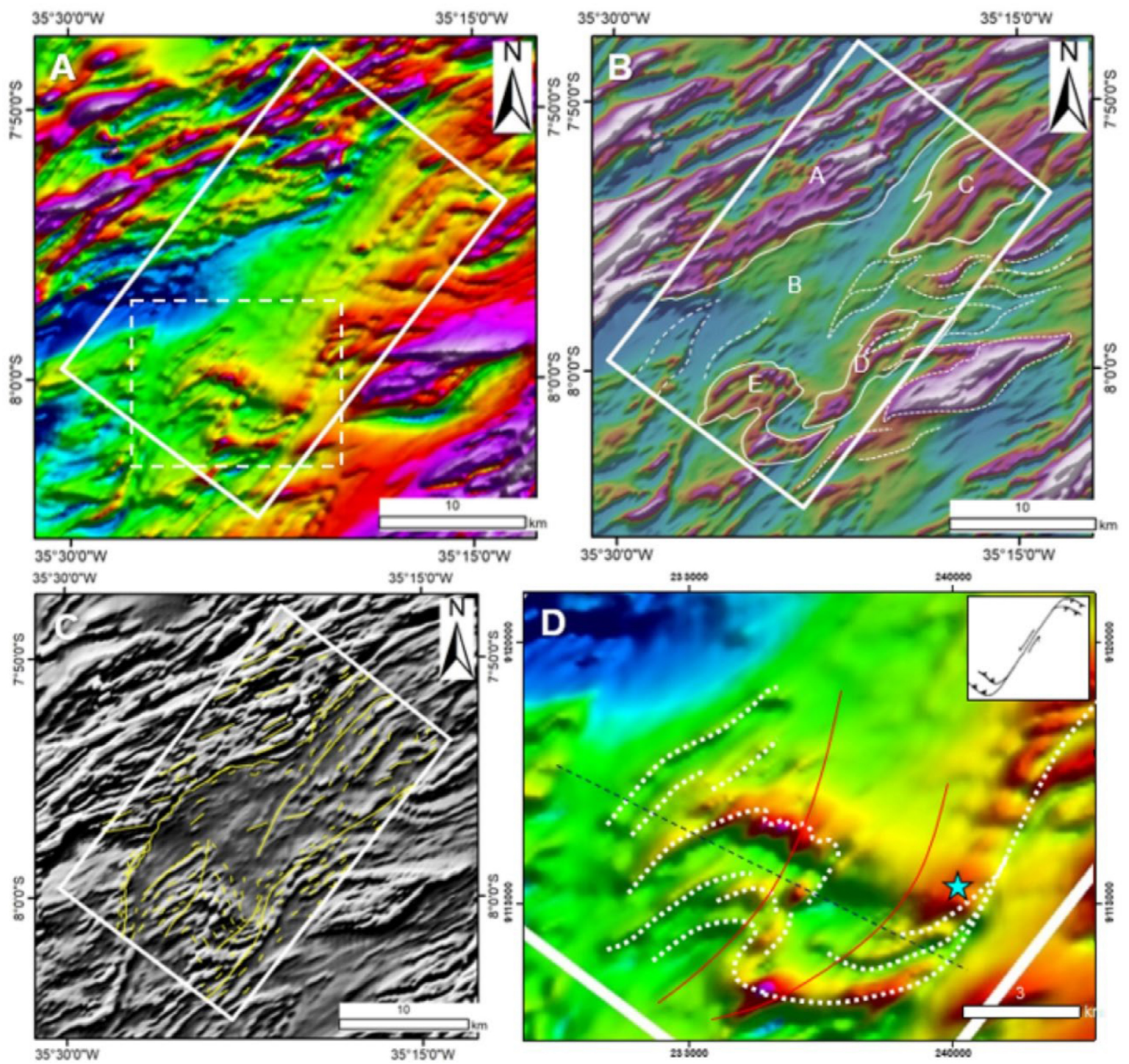

Figure 2. Magnetometric Maps: (A) total magnetic field anomaly map; (B) reduction to pole map with magnetic domains and inferred sigmoidal magnetic anomalies; (C) vertical derivative map with inferred magnetic lineaments; (D) total magnetic field anomaly map in the south of the study area showing the inferred fold axial traces and its relationship with the Glória do Goitá Shear Zone. The star indicates an outcrop where reverse shear bands of top-to-the-SW transport were found. The sketch shows the possible thrusting related to transcurrent shear zones with such geometry and kinematics.

\section{RESULTS}

\section{Aeromagnetometry}

Five magnetic domains were individualized using the Reduction to Pole Map (Fig. 2B) and correlated to field and literature data:

- Domain A generally exhibits high magnetic intensity and is separated from Domain B by a well-defined magnetic lineament related to the Paudalho Shear Zone. It comprises basement orthogneisses (Vertentes and Salgadinho complexes). Although aeromagnetometry did not allow us to distinguish between them, magnetic susceptibility measures using a KT-10 kappameter showed higher values for the Salgadinho Complex. The extreme south of this domain, where intensity values are relatively low, corresponds to the Passira Gabbro-Anorthositic Complex and Bengala Orthogneiss;
- Domain B has a less rough texture than Domain A, with low values of magnetic intensity; it corresponds to the Surubim-Caroalina Complex;

- Domains C and D are domains of rough texture, with high values of magnetic intensity and anomalies with sigmoidal geometry. Domain C comprises the Surubim Complex, with rocks locally affected by an unnamed sinistral shear zone. Domain D comprises basement orthogneisses and is related to the Glória do Goitá Shear Zone;

- Domain E also shows rough magnetic texture and high values of magnetic intensity. It comprises the Açudinho and Terra Nova orthogneisses and the Vertentes Complex. It also outlines a synformal-antiformal pair which presents NE-SW axial traces gently bent.

Magnetic lineaments traced from the Vertical Derivative Map (Fig. 2C) suggest NE-SW-striking features, sometimes sigmoidal, 
that can be related to field structures. Most of these features are also seen in other magnetometric maps. The Total Magnetic Field Anomaly and Reduction to Pole maps show NE-SW sigmoidal anomalies suggesting sinistral movement (Figs. 2A and 2B) which are mainly coincident with the shear zones. The folding of Domain E is better observed in the Total Magnetic Field Map, where it is more continuous and shows an apparent inflection of its axial traces. The continuity between domains $\mathrm{D}$ and E suggests that these folds and the Glória do Goitá Shear Zone are genetically associated, as pointed out by Lima et al. (2015b), and define a horse-tail ending for the latter (Fig. 2D).

\section{Structural geology}

\section{Thrust tectonics}

Contour plots of poles to foliation in the study area indicate the prevalence of a flat-lying to SE-moderately-dipping foliation (main foliation $/ \mathrm{S}_{\mathrm{p}}$ ) in the Brasiliano-age Açudinho and Terra Nova orthogneisses, metasedimentary rocks, and basement orthogneisses, being more systematic in the latter (Figs. 3A, 3B and 3C). In basement rocks, a local previous metamorphic foliation delineates intrafolial folds, which allows naming $S_{p}$ as $S_{2}$ (Fig.3D). This previous foliation is also observed petrographically
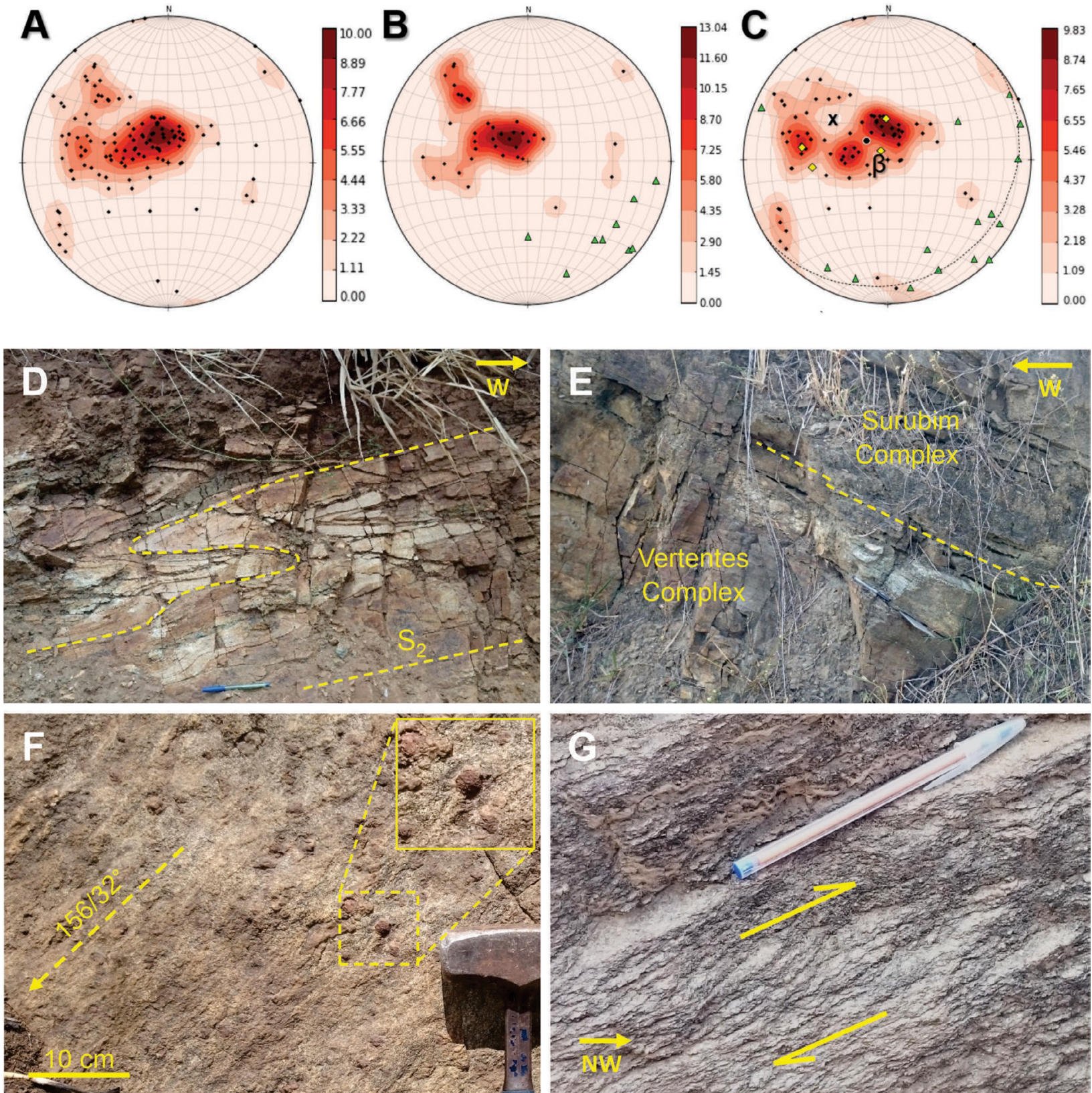

Figure 3. (A) Lower hemisphere, equal area projection of poles to foliation $\left(S_{2}, S_{3}\right)$ in the study area $(n=126)$; (B) Contour plots of poles to foliation $\left(S_{2}, S_{3}\right)$ in basement rocks $(n=38$; circles $)$ and lineation plots $\left(n=9\right.$; triangles); (C) Contour plots of poles to foliation $\left(S_{2}, S_{3}\right)$ in metasedimentary rocks $(n=81)$ and lineation plots $(n=14$; triangles); " $\mathrm{x}$ " indicates the approximate pole to a small circle defined by the contour plots of poles to foliation; the $\beta$ axis was calculated from the great circle defined by lineations. Yellow plots correspond to poles to foliation from Açudinho and Terra Nova orthogneisses; (D) Older foliation defining a tight to isoclinal intrafolial fold (profile view) with an axial plane parallel to $\mathrm{S}_{2}$ (Vertentes Complex); (E) Contact between Vertentes and Surubim complexes along with the Paudalho Shear Zone (profile view); (F) Surubim Complex paragneiss with stretching lineation (azimuth, plunge) in plain view marked by pressure shadows in garnet (right upper corner); (G) Surubim Complex paragneiss with shear bands $\left(132^{\circ} / 16^{\circ}\right.$ (dip direction, dip) indicating a top-to-the-northwest sense of shear. 
in micaschist and paragneiss, being defined by rare kink biotite porphyroblasts and biotite inclusions in garnet that are orthogonal or oblique to $S_{2}$ (Silva et al.2020). Stretching mineral lineations have dominantly low plunge and medium to high rake and are marked by quartz, feldspar, sillimanite, amphibole, and pressure shadows around garnet (Fig. 3F). The lineations are less scattered in basement rocks, where they are southeast-plunging, and, locally, south-plunging (Fig. 3B).

Strain localization during $\mathrm{S}_{2}$ development is represented by the Paudalho Shear Zone (PSZ), which is marked by mylonites and protomylonites. The contact between the basement and metasedimentary rocks observed across the PSZ shows that the banding of the basement orthogneiss and the mylonitic foliation of the metasedimentary rocks $\left(\mathrm{S}_{2}\right)$ are parallel to each other and to the contact (Fig. 3E). The PSZ also has a sinistral component, which is detailed in the following section (Strike-slip tectonics). Kinematic indicators in metasedimentary rocks and along with the aforementioned contact indicate a top-to-thenorthwest sense of shear, pointing out a contractional regime (Fig. 3G). Basement rocks present strong planar fabric and kinematic indicators were not found. Mylonitic foliation related to $\mathrm{S}_{2}$ is also observed in the west limb of the major synform, along with the Brasiliano orthogneisses and metasedimentary rocks, suggesting that its development started during the thrusting.

In all mapped units, microstructures related to the regional foliation include quartz grains showing dynamic recrystallization by grain boundary migration (Fig. 4A), including chessboard extinction (Fig. 4B), overlapped by subgrain rotation and bulging recrystallization (Figs. 4C and 4D). Undulose extinction and deformation bands are ubiquitous. Feldspar show subgrain formation (locally), flame perthite, myrmekite intergrowth in the edges of the grains, undulose extinction, deformation twins, and kink bands.

\section{Strike-slip tectonics}

Steep mylonitic foliation characterizes the Glória do Goitá Shear Zone (GGSZ) (Fig. 5A) and an unnamed smaller shear zone in the north of the study area (Fig. 5B). Sinistral sense of shear in both of them is indicated by $\mathrm{S}-\mathrm{C}$ fabrics and shear bands in mylonites (Fig. 5C) together with regional sigmoidal magnetic anomalies (Fig. 2).

Previous works (Accioly et al. 2000, Lima et al. 2015a, 2015b) defined the PSZ only as a thrust shear zone, though, a sinistral component was also documented in this study. At the northern portion of the structure, a moderate to steep foliation predominates $\left(30-70^{\circ}\right)$ (Fig. 1). Additionally, subhorizontal low rake lineations occur locally across the PSZ. These observations allow classifying the PSZ as a thrust (or thrust sinistral) shear zone at the southern portion, and as a sinistral thrust at the northern portion of the study area.

Brittle-ductile shear zones and pseudotachylyte veins occur in the northern portion of the PSZ and in unnamed shear zones (Fig. 5D), indicating late reactivation of these structures. This is further supported by cataclastic microstructures and mesoscopic cataclastic zones.

Microstructural data for the GGSZ are scarce, due to intense weathering of most outcrops or to smooth paving slabs in others, making it too hard to sample by hammering. A protomylonite sample from the GGSZ shows features such as feldspar porphyroclasts wrapped by mica, stretching of some quartz grains, and mica fish. Grain boundary migration mechanisms predominate in quartz grains, including chessboard extinction (Fig. 4E), and are overlapped by bulging recrystallization and cataclasis. Feldspar crystals show local bulging and common deformation twins, and biotite shows strong undulose extinction and local kink bands.

\section{Folds}

The macroscopic synformal-antiformal pair, which comprises a NW-verging tight fold (synform) and an upright tight fold (antiform), both SW-plunging, is the most remarkable structural feature in the study area (Fig. 2C). The bending of their NE-SW axial traces (Fig. 1C), especially of the synform, indicates refolding by a subsequent folding phase (Lima et al.2015b; this work), featuring a type 3 interference pattern (Ramsay 1967). Mesoscopic tight inclined folds, locally with gently curved axial planes (Fig. 5E), and open upright folds (Fig. 5F) are probably related to these two folding phases.

In the eastern limb of the macroscopic antiform, decimeter-scale reverse shear bands with a top-to-the-SW sense of shear occur locally, cutting across $\mathrm{S}_{3}$ (Fig. 5G). These bands are in accordance with the horsetail termination suggested for the GGSZ.

\section{DISCUSSION}

We interpret foliations and folds in the Feira Nova region to having been formed during two ductile deformation stages that together represent a progressive tectonic evolution rather than a polycyclic one. The parallelism between the gneissic banding in basement orthogneisses, the schistosity in metasedimentary rocks, and of their contact across the PSZ (Fig. 3C) support that these fabrics $\left(\mathrm{S}_{2}\right)$ were produced during the same tectonic event. Contour plots of pole to foliation also show comparable attitudes for the two lithotypes and for Neoproterozoic orthogneisses (Açudinho and Terra Nova) (Figs. 3A and 3C), supporting that these structures nucleated during the Brasiliano Orogeny. Lima et al. (2015b), on the other hand, suggests that the gneissic banding belongs to a distinct former deformation phase (older than $1.7 \mathrm{Ga}$ ), based on metamafic dikes that cut across the banding and were correlated with the 1.7 Ga-old Passira Complex (Accioly 2000). For these authors, the flat-lying fabric would have been acquired later, sometime between 1.7 and $0.6 \mathrm{Ga}$. In this work, structures prior to $S_{2}$ are limited to a local isoclinally folded foliation present in basement rocks (Fig. 3B) and seen petrographically in both basement and Neoproterozoic supracrustal units (Silva et al.2020). Therefore, this foliation also belongs to the contractional regime and the mentioned dikes may actually be younger than what Accioly (2000) proposed, being related to the late stages of the Brasiliano Orogeny.

As well as the regional fabric, both Terra Nova and Açudinho orthogneisses show a flat-lying to gently dipping foliation (although affected by folding) (Fig. 1C), which indicates that these units are older or coeval to the contractional regime, 

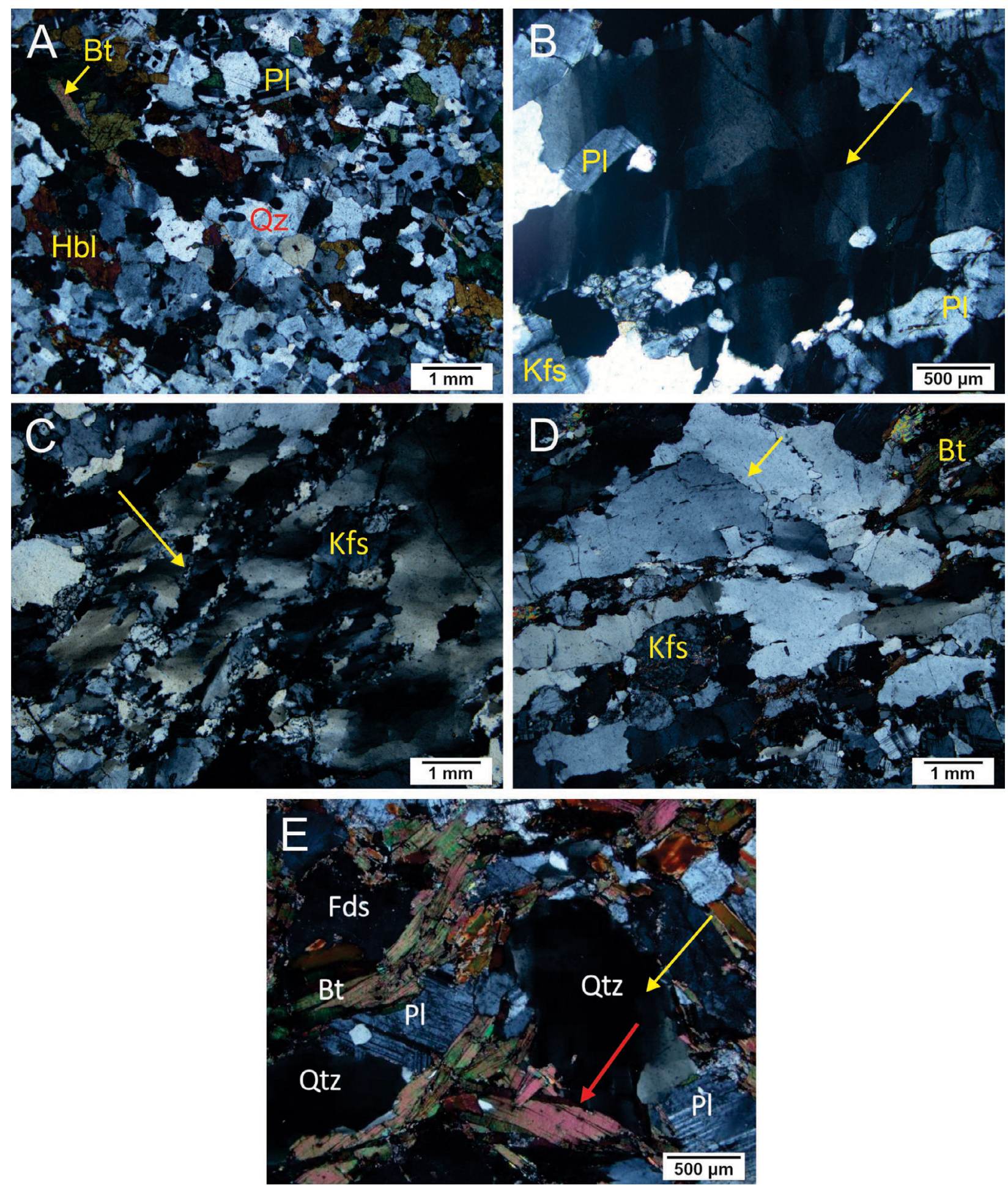

Qtz: quartz; Bt: biotite; Kfs: K-feldspar; Fds: feldspar; Pl: plagioclase; Hbl: hornblende.

Figure 4. Deformation mechanisms in the study area. (A, B, C, and D) are related to the flat-lying foliation; (A) Quartz chessboard extinction (arrow) in the Terra Nova Orthogneiss. (B) Grain boundary migration in the Salgadinho Complex. (C) Bulging recrystallization (arrow) in the Terra Nova orthogneiss; (D) Bulging recrystallization (arrow) overlapping grain boundary migration in the Açudinho Orthogneiss; (E) Mica fish (red arrow) and quartz chessboard extinction (yellow arrow) in protomylonite from the Gloria do Goitá Shear Zone.

and thus, pre-transcurrent at least. Also, the age of Terra Nova Orthogneiss $(617 \pm 8.8 \mathrm{Ma})$ (Lima et al. 2015a) is within the regional time span attributed to pre-transcurrent plutons (630-590 Ma) (e.g., Guimarães et al. 2004, Neves et al.2006b, 2020, Van Schmus et al. 2011, Araújo et al. 2014). Lima et al. (2015b) interpreted the Terra Nova Orthogneiss as a marker of a contractional phase with a top-to-the-NW sense of shear.
Lima et al. (2015a), on the other hand, interpreted the Terra Nova Orthogneiss as indicating a syn-orogenic transtensional event based on its relationship with the GGSZ and a geochemical signature suggestive of an extensional setting. However, the geochemistry may be reflecting the nature of the source and not the tectonic setting of intrusion. This inference about the influence of the source is consistent with the nearby occurrence 

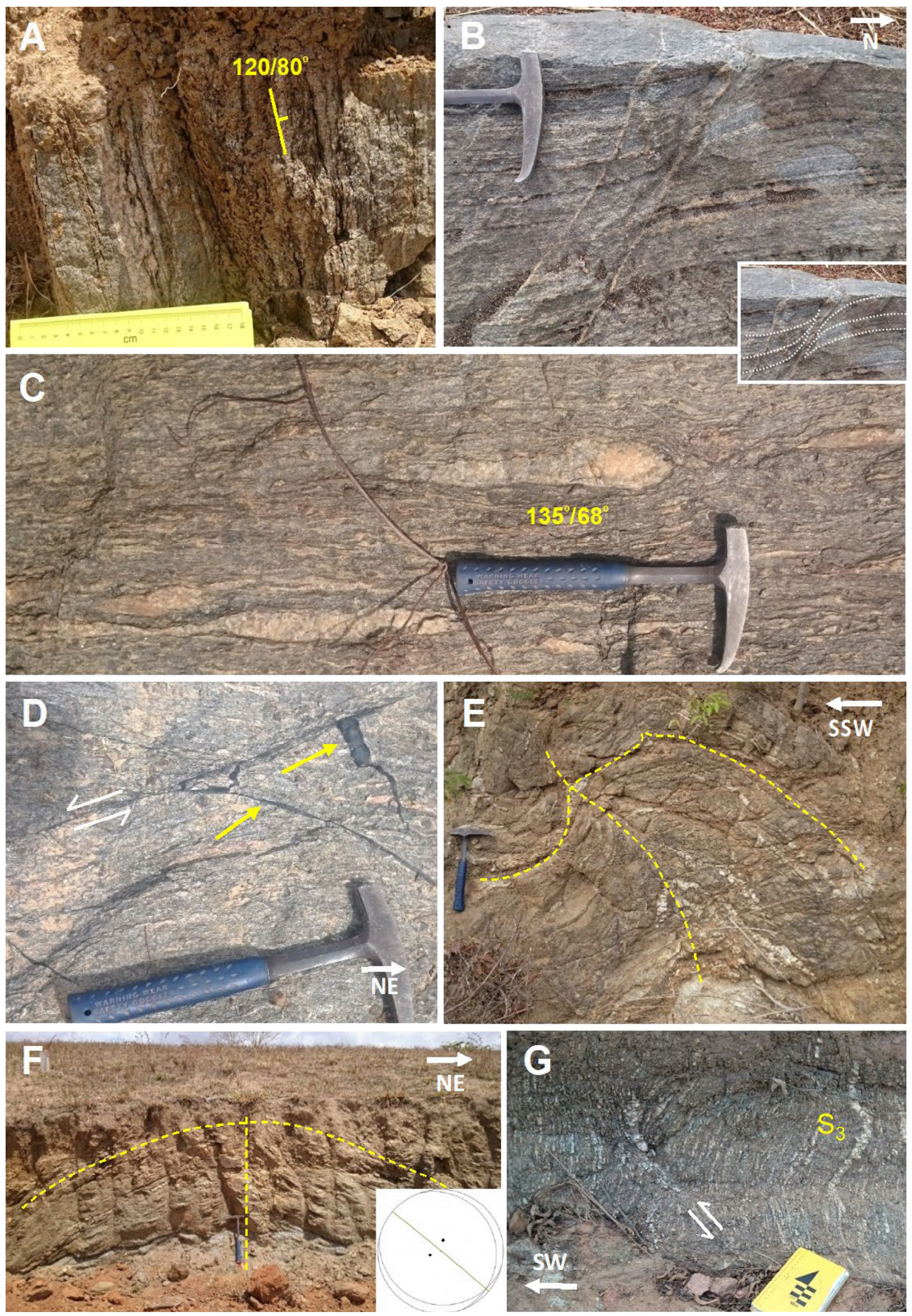

Figure 5. Structures related to the transpressional regime. (A) Subvertical foliation in mylonitic paragneiss from Surubim Complex related to the Glória do Goitá Shear Zone; (B) sinistral shear band related to the Paudalho Shear Zone (Salgadinho Complex; plain view); (C) plain view of stretched quartz veins in mylonitic paragneiss (Surubim Complex) related to the northern shear zone (Silva et al. 2020); (D) Pseudotachylytes (arrow) in mylonitic paragneiss (Surubim Complex; plain view); (E) Inclined tight fold with a gently curved axial plane (Vertentes Complex; profile view); (F) Open upright fold with the projection of limbs indicating a subhorizontal NW axis (Surubim Complex); (G) Reverse shear bands with top-to-the-SW transport cutting across steep foliation $\left(\mathrm{S}_{3}\right)$ (Surubim Complex; profile view). 
of the Passira metagabbro-anorthositic Complex (Accioly et al. 2000), indicating that sources with intraplate characteristics may be present in depth. Along with the absence of structural data suggesting syn-orogenic extension (or transtension), it is therefore more likely that the Terra Nova Orthogneiss intruded Surubim Complex as sheets along its foliation in the contractional regime (as previously suggested by Lima et al. 2015b), and was later affected by transcurrent/transpressive deformation.

The microstructures related to both flat-lying and steep foliation (Fig. 4) suggest that temperature conditions were high during thrusting, remained high during strike-slip deformation (e.g., chessboard extinction in quartz), and then migrated to lower ones (e.g., bulging recrystallization in quartz). Using conventional garnet-biotite geothermometer, garnet- $\mathrm{Al}_{2} \mathrm{SiO}_{5}$-quartz-plagioclase (GASP) geobarometer, and $\mathrm{X}$-ray maps, Silva et al. (2020) estimated metamorphic peak conditions of $650-760^{\circ} \mathrm{C}$ and $\sim 0.6-0.9 \mathrm{GPa}$ for the Surubim Complex in the study area, coeval with the development of flat-lying foliation and local anatexis. Garnet rims indicated 590-520 ${ }^{\circ} \mathrm{C}$ and 0.4-0.3 GPa, which was interpreted as exhumation with low erosional and cooling rates. In the study area, a mean age of $592 \pm 2$ Ma yielded by monazite grains from the Surubim Complex (Neves et al., 2021) is consistent with regional early- to syn-transcurrent ages, also suggesting the persistence of high-temperature conditions.

Nucleation of the antiformal-synformal pair probably represents the transition from a contractional to a transpressive regime. Shearing of pre-existing folds, regardless of their initial orientation, tends to rotate them toward parallelism with the shear direction (e.g., Escher and Waterson 1974, Carreras et al. 2005, Carreras and Druguet 2019). The accordance between the vergence of these folds and the regional transport (northwest) suggests they nucleated during the contractional regime. This inference is also supported by the occurrence of a small reverse shear zone in the western limb of the synform (Fig. 1C), which was possibly formed by limb disruption. Subsequent rotation and steepening of the folds' axial planes can be attributed to transpression coeval with the development of the GGSZ.

The orientation of the fold axes that caused the refolding observed at map scale can be inferred through the analysis of contour plots of poles to foliation and lineations (Fig. 3C). In the first case, they define a small circle centered at $307^{\circ} / 51^{\circ}$ (trend, plunge). In the second, lineations define a great circle, probably resulting from the dispersion of originally SE-plunging lineations (e.g., Duebendorfer 2003), with a NW-plunging pole $\left(312^{\circ} / 75^{\circ}\right)$. Refolding may be explained by a local SW-NE shortening component developed to accommodate ductile strain at the GGSZ termination, once shear-related folds tend to nucleate at a high angle to the shear direction (Carreras et al.2005). So, the formation of the late folds would not have required changing the orientation of regional stress axes (e.g., Neves et al.2018) and most likely constitutes part of the same progressive deformation. Indeed, type 3 interference patterns have been described as a product of progressive or even coeval deformation (e.g., Forbes et al. 2004, Baird and Shrady 2011, Fossen et al.2013, Carreras and Druguet 2019) and explained by limbs that steepened enough to shorten and buckle transversally (Fossen et al.2013) or by curving of axial surfaces due to instabilities in them (Carreras and Druguet 2019).

In synthesis, the results of this study indicate that the structural evolution of the Feira Nova region resulted from a progressive sequence of events (Fig. 6):
1.

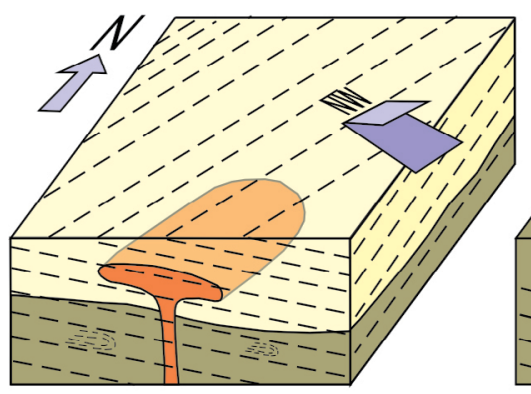

4.

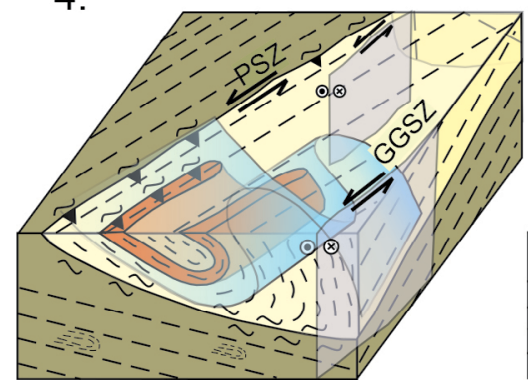

2

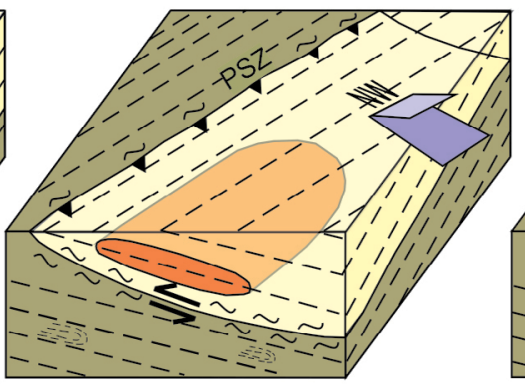

5.

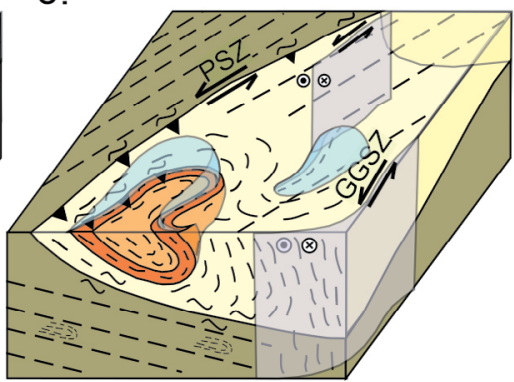

3

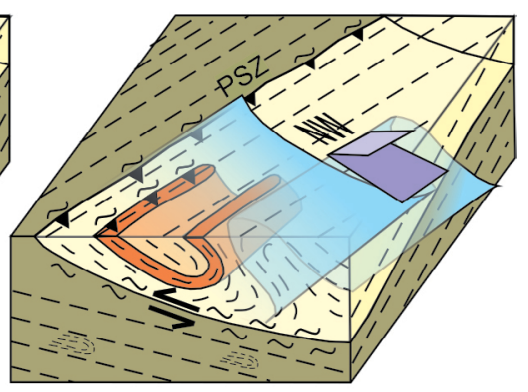
Figure 6. Simplified schematic block diagrams depicting the structural evolution of the study area. (1) Distributed non-coaxial shear with
top-to-the-NW tectonic transport and intrusion of the Terra Nova orthogneiss during the development of a flat-lying foliation; (2) nucleation of the PSZ along with the contact between the basement and supracrustal rocks; (3) development of folds induced by the top-to-the-NW tectonics; (4) transition to transpressive tectonics with nucleation of GGSZ and local steepening of PSZ and antiform limbs; (5) Refolding related to local SW-NE shortening developed to accommodate ductile strain at the shear zone termination. 
- Thrusting produced a regional flat-lying foliation associated with non-coaxial shear with top-to-the-northwest tectonic transport. Strain localization along the contact of the Surubim Complex with basement rocks gave rise to the PSZ;

- Probably due to rheological contrasts resulting from intercalation of orthogneisses with metasedimentary rocks, folds were developed at the advanced stages of this contractional phase, producing northwest-verging macroscopic folds;

- Crustal thickening resulting from shortening may have induced escape tectonics and development of the GGSZ. The transition from thrusting to transpression is supported by the local steepening of the PSZ and of the axial plane of the macroscopic antiformal fold;

- The growing GGSZinduced the development of NW-trending folds and reverse shear bands at its terminations. The evolution proposed is in line with propositions that multiple deformation fabrics can be explained by progressive deformation rather than by several temporarily separated events (i.e., polycyclic deformation) (e.g., Holdsworth 1990, Connors and Lister 1995, Forster and Lister 2008, Fossen et al. 2019, Fossen 2019, Bhattacharya et al. 2019).

An alternative interpretation compatible with the structures observed in the study area would involve contemporaneous development of the PSZ and GCSZ. In this case, strain partitioning would have resulted in dip-slip-dominated transpression in the west and strike-slip-dominated transpression in the east. We consider this to be na unlikely possibility, given the regional context. Indeed, $\mathrm{U}-\mathrm{Pb}$ dating of regional deformation and metamorphism and of pre-transcurrent plutons has consistently yielded ages older than $600 \mathrm{Ma}$ whereas syntranscurrent plutons are usually younger than $590 \mathrm{Ma}$ (Guimarães et al. 2004, Neves et al. 2006a, 2006b, 2008, 2020, Archanjo et al. 2008, Van Schmus et al. 2011). Therefore, it is more likely that the GGSZ post-dates the development of the PSZ.

\section{CONCLUSIONS}

Structural and geophysical data suggest two ductile deformation stages for the Feira Nova region, both related to the Brasiliano Orogeny. The first is a contractional stage that produced flat-lying foliation $\left(\mathrm{S}_{2}\right)$ with a top-to-the-NW sense of shear and location of deformation represented by the reverse component of PSZ. $\mathrm{S}_{2}$ transposed a previous local foliation, also belonging to this regime, and which locally define isoclinal folds. NW-verging folds were nucleated later during this deformation event and steepened during the subsequent transpression. Transpression produced a steep mylonitic foliation associated with sinistral transcurrent shear zones, including GGSZ and a sinistral component of PSZ. As the GGSZ developed, local shortening was yielded on its SW termination, leading to nucleation of $\mathrm{NW}$-trending open folds that refolded the earlier formed folds and produced a type 3 interference pattern. The data are consistent with transition from a contractional to a transpressive regime, related to progressive rather than polycyclic deformation.

\section{ACKNOWLEDGMENTS}

We are thankful to the late Votorantim Metais for funding this work and to Wilson R. A. Freitas, for his technical support. For their constructive comments, we thank José M. Rangel da Silva, Lauro C. M. L Santos, the reviewers Alain Vauchez and Sebastián Oriolo, and the editor Haakon Fossen. V.L.S. also thanks $\mathrm{CNPq}$ for the scholarship.

\section{ARTICLE INFORMATION}

Manuscript ID: 20200049. Received on: 06/17/2020. Approved on: 10/07/2020.

V.L.S. collected most of the data used, wrote the first draft of the manuscript, and prepared the figures; S.P.N. collected data, provided advisorship regarding regional and structural geology, and improved the manuscript through corrections and suggestions. Competing interests: The authors declare no competing interests.

\section{REFERENCES}

Accioly A.C.A. 2000. Geologia, Geoquímica e Significado Tectônico do Complexo Metanortosítico de Passira - Província Borborema - Nordeste Brasileiro. Thesis, Instituto de Geociências, Universidade de São Paulo, São Paulo, 168p

Accioly A.C.A., McReath I., Santos E.J., Guimarães I.P., Santos A.C. 2003. The Ages of Crystallization and Metamorphism of the Passira Anorthosite Complex Borborema Province, Northeastern Brazil. In: South American Symposium on Isotope Geology, 4., Salvador. Proceedings ..., p. 487-490.

Accioly A.C.A., McReath I., Santos E.J., Guimarães I.P., Vannuci R., Bottazzi R. 2000. The Passira meta-anorthositic complex and its tectonic implication, Borborema Province, Brazil. In: International Geological Congress, 31., Rio de Janeiro. Proceedings ... International Union of Geological Sciences.

Almeida F.F.M., Hasui Y., Brito Neves B.B., Fuck R. 1981. Brazilian Structural Provinces: An introduction. Earth Science Reviews, 17(1-2):1-29. https://doi.org/10.1016/0012-8252(81)90003-9

Araújo C.E.G., Weinberg R.F., Cordani U.G. 2014. Extruding the Borborema Province (NE-Brazil): a two-stage Neoproterozoic collision process. Terra Nova, 26(2):157-168. https://doi.org/10.1111/ter.12084
Archanjo C.J., Hollanda M.H.B.M., Rodrigues S.W.O., Brito Neves B.B., Armstrong R. 2008. Fabrics of pre- and syntectonic granite plutons and chronology of shear zones in the Eastern Borborema Province, NE Brazil. Journal of Structural Geology, 30(3), 310-326. https://doi.org/10.1016/j. jsg.2007.11.011

Archanjo C.J., Trindade R.I., Bouchez J.L., Ernesto M. 2002. Granite fabrics and regional-scale strain partitioning in the Seridó belt (Borborema Province, NE Brazil). Tectonics, 21(1):1-14. https://doi.org/10.1029/2000TC001269

Archanjo C.J., Viegas L.G.F., Hollanda M.H.B.M., Souza L.C., Liu D. 2013. Timing of the HT/LP transpression in the Neoproterozoic Seridó Belt (Borborema Province, Brazil): Constraints from U-Pb (SHRIMP) geochronology and implications for the connections between NE Brazil and West Africa. Gondwana Research, 23(2):701-714. https://doi. org/10.1016/j.gr.2012.05.005

Baird G.B., Shrady C.H. 2011. Timing and kinematics of deformation in the northwest Adirondack Lowlands, New York State: Implications for terrane relationships in the southern Grenville Province. Geosphere, 7(6):1303-1323. https://doi.org/10.1130/GES00689.1 
Baranov V., Naudy H. 1964. Numerical Calculation of the Formula of Reduction to the Magnetic Pole. Geophysics, 29(1):67-79. https://doi. org/10.1190/1.1439334

Bhattacharya A., Rekha S., Sequeira N., Chatterjee A. 2019. Transition from shallow to steep foliation in the Early Neoproterozoic Gangpur accretionary orogen (Eastern India): Mechanics, significance of mid-crustal deformation, and case for subduction polarity reversal? Lithos, 348-349:105196. https:// doi.org/10.1016/j.lithos.2019.105196

Carreras J., Druguet E. 2019. Complex fold patterns developed by progressive deformation. Journal of Structural Geology, 125:195-201. https://doi.org/10.1016/j.jsg.2018.07.015

Carreras J., Druguet E., Griera A. 2005. Shear zone-related folds. Journal of Structural Geology, 27(7):1229-1251. https://doi.org/10.1016/j. jisg.2004.08.004

Connors K.C., Lister G.S. 1995. Polyphase deformation in the western Mount Isa Inlier, Australia: episodic or continuous deformation? Journal of Structural Geology, 17(3):305-328. https://doi.org/10.1016/0191-8141(94)00057-7

Dantas E.L., Silva A.M., Almeida T., Moraes R.A.V. 2003. Old geophysical data applied to modern geological mapping problems: a case-study in the Seridó Belt, NE Brazil. Revista Brasileira de Geociências, 33(2 Suppl.):65-72.

Duebendorfer E.M. 2003. The interpretation of stretching lineations in multiply deformed terranes: an example from the Hualapai Mountains, Arizona, USA. Journal of Structural Geology, 25(9):1393-1400. https://doi. org/10.1016/S0191-8141(02)00203-1

Escher A., Waterson J. 1974. Stretching fabrics, folds and crustal shortening. Tectonophysics, 22(3-4):223-231. https://doi. org/10.1016/0040-1951(74)90083-3

Forbes C.J., Betts P.G., Lister G.S. 2004. Synchronous development of Type 2 and Type 3-fold interference patterns: evidence for recumbent sheath folds in the Allendale Area, Broken Hill, NSW, Australia. Journal of Structural Geology, 26(1):113-126. https://doi.org/10.1016/ S0191-8141(03)00074-9

Forster M.A., Lister G.S. 2008. Tectonic sequence diagrams and the structural evolution of schists and gneisses in multiply deformed terranes. Journal of Geological Society, 165(5):923-939. https://doi. org/10.1144/0016-76492007-016

Fossen H. 2019. Writing papers with an emphasis on structural geology and tectonics: advices and warnings. Brazilian Journal of Geology, 49(4):1-6. https://doi.org/10.1590/2317-4889201920190109

Fossen H., Cavalcante G.C., Pinheiro R.V.L., Archanjo C.J. 2019. Deformation - progressive or multiphase? Journal of Structural Geology, 125:82-99. https://doi.org/10.1016/j.jsg.2018.05.006

Fossen H., Teyssier C., Whitney D.L. 2013. Transtensional folding. Journal of Structural Geology, 56:89-112. http://doi.org/10.1016/j.jsg.2013.09.004

Goscombe B.D., Gray D.R. 2008. Structure and strain variation at midcrustal levels in a transpressional orogen: A review of Kaoko Belt structure and the character of West Gondwana amalgamation and dispersal. Gondwana Research, 13(1):45-85. https://doi.org/10.1016/j.gr.2007.07.002

Gray M.B., Mitra G. 1999. Ramifications of four-dimensional progressive deformation in contractional mountain belts. Journal of Structural Geology, 21(8-9), 1151-1160. https://doi.org/10.1016/S0191-8141(99)00059-0

Guimarães I.P. 1989. The petrological evolution and tectonic associations of the Bom Jardim Complex, Pernambuco State, NE Brazil. Thesis, University of London, London, 423p.

Guimarães I.P., Silva Filho A.F. 1992. Evolução petrológica e geoquímica do complexo Bom Jardim, Pernambuco. Revista Brasileira de Geociências, 22(1):29-42.

Guimarães I.P., Silva Filho A.F., Almeida C.N., Van Schmus W.R., Araújo J.M.M., Melo S.C., Melo E.B. 2004. Brasiliano (Pan-African) granitic magmatism in the Pajeú-Paraíba belt, Northeast Brazil: an isotopic and geochronological approach. Precambrian Research, 135(1-2):23-53. https://doi.org/10.1016/j.precamres.2004.07.004

Holdsworth R.E. 1990. Progressive deformation structures associated with ductile thrusts in the Moine Nappe, Sutherland, N. Scotland. Journal of Structural Geology, 12(4):443-452. https://doi. org/10.1016/0191-8141(90)90033-U
Lima H.M., Ferreira V.P., Santos E.J., Pimentel M.M., Santos L.C.M.L. 2015a. Origem, significado petrogenético e idade dos ortognaisses Terra Nova: registro de magmatismo alcalino transtensional Neoproterozoico no domínio da zona transversal da Província Borborema. Geochimica Brasiliensis, 29(2):70-86. http://doi.org/10.21715/GB2358-2812.2015292070

Lima H.M., Pimentel M.M., Santos L.C.M.L., Mendes V.A. 2017. Análise tectônica da porção Nordeste da Faixa Sergipana, Província Borborema: Dupla vergência em resposta a colisão oblíqua entre o cráton do São Francisco e o Terreno Pernambuco-Alagoas. Geonomos, 25(2):20-30. https://doi.org/10.18285/geonomos.v25i2.1078

Lima H.M., Santos E.J., Santos L.C.M.L. 2015b. Compartimentação estrutural da faixa Feira Nova e blocos adjacentes: Implicações para a evolução do terreno Rio Capibaribe da Província Borborema, NE do Brasil. Revista Brasileira de Mineração e Meio Ambiente, 5(2):32-38.

Melo A.A., Siqueira L.P. 1971. Novas considerações sobre a geologia do précambriano de Pernambuco Oriental. Revista da Associação dos Geólogo de Pernambuco, 1(2):32-41.

Milligan P.R., Gunn P.J. 1997. Enhancement and presentation of airborne geophysical data. AGSO Journal of Australian Geology and Geophysics, 17(2):63-75

Neves S.P., Bruguier O., Bosch D., Silva J.M.R., Mariano G. 2008. U-Pb ages of plutonic and metaplutonic rocks in southern Borborema Province (NE Brazil): Timing of Brasiliano deformation and magmatism. Journal of South American Earth Science, 25(3):285-297. https://doi.org/10.1016/j. jsames.2007.06.003

Neves S.P., Bruguier O., Vauchez A., Bosch D., Silva J.M.R., Mariano G. 2006a. Timing of crustal formation, deposition of supracrustal sequences and Transamazonian and Brasiliano metamorphism in eastern Borborema Province (NE Brazil): Implications for western Gondwana assembly. Precambrian Research, 149(3-4):197-216. https://doi.org/10.1016/j. precamres.2006.06.005

Neves S.P., Lages G.A., Brasilino R.G., Miranda A.W.A. 2015 Paleoproterozoic accretionary and collisional processes and the build-up of the Borborema Province (NE Brazil): geochronological and geochemical evidence from the Central Domain. Journal of South American Earth Science, 58:165-187. http://doi.org/10.1016/j.jsames.2014.06.009

Neves S.P., Mariano G. 1999. Assessing the tectonic significance of large-scale transcurrent shear zone system: the Pernambuco lineament, northeastern Brazil. Journal of Structural Geology, 21(10):1369-1383. https://doi.org/10.1016/S0191-8141(99)00097-8

Neves S.P., Mariano G., Correia P.B., Silva J.M.R. 2006b. 70 m.y. of synorogenic plutonism in eastern Borborema Province (NE Brazil): temporal and kinematic constraints on the Brasiliano Orogeny. Geodinamica Acta, 19(3-4):213-236. https://doi.org/10.3166/ga.19.213-236

Neves S.P., Santos T.A.S., Medeiros P.C., Amorim L.Q. Casimiro D.C.G 2018. Interference fold patterns in regional unidirectional stress fields; a result of local kinematic interactions. Journal of Structural Geology, 115:304-310. https://doi.org/10.1016/j.jsg.2018.04.012

Neves S.P., Silva J.M.R., Bruguier O. 2017. Geometry, kinematics and geochronology of the Sertânia Complex (central Borborema Province, NE Brazil): Assessing the role of accretionary versus intraplate processes during West Gondwana assembly. Precambrian Research, 298:552-571. http://doi. org/10.1016/j.precamres.2017.07.006

Neves S.P., Silva J.M.R., Mariano G. 2005. Oblique lineations in orthogneisses and supracrustal rocks: vertical partitioning of strain in a hot crust (eastern Borborema Province, NE Brazil). Journal of Structural Geology, 27(8):1513-1527. https://doi.org/10.1016/j.jsg.2005.02.002

Neves S.P., Teixeira C.M.L., Bruguier O. 2020. Long-lived localized magmatism in central-eastern part of the Pernambuco-Alagoas Domain, Borborema Province (NE Brazil): Implications for tectonic setting, heat sources, and lithospheric reworking. Precambrian Research, 337:1055592. https://doi.org/10.1016/j.precamres.2019.105559

Neves S.P., Teixeira C.M.L., Silva V.L. 2021. Evolução Térmica Prolongada do Complexo Surubim: Implicações para a Evolução Tectônica da Província Borborema (NE do Brasil) durante a Amalgamação do Gondwana Ocidental. In: Congresso Brasileiro de Geologia, 50., Brasília. Proceedings ...

Ramsay J.G. 1967. Folding and Fracturing of Rocks. New York: McGraw-Hill, $568 \mathrm{p}$. 
Braz. J. Geol. (2021), 51(1): e20200049

Sá J.M., Bertrand J.M., Leterrier J., Macedo M.H.F. 2002. Geochemistry and geochronology of pre-Brasiliano rocksfrom the TransversalZone, Borborema Province, Northeast Brazil. Journal of South American Earth Sciences, 14(8):851-866. https://doi.org/10.1016/S0895-9811(01)00081-5

Santos E.J., Medeiros V.C. 1999. Constraints from granitic plutonism on proterozoic crustal growth of the Transverse Zone, Borborema Province, NE-Brazil. Revista Brasileira de Geociências, 29(1):73-84. https://doi. org/10.25249/0375-7536.1999297384

Santos E.J., Nutman A.P., Brito Neves B.B. 2004. Idades SHRIMP U-Pb do Complexo Sertânia: implicações sobre a evolução tectônica da Zona Transversal, Província Borborema. Geologia USP. Série Científica, 4(1):1-12. http://doi.org/10.5327/s1519-874x2004000100001

Silva V.L, Pereira S., Bustamante A., Neves S.P. 2020. Metamorphic evolution of metasedimentary rocks of the Feira Nova region: Tectonic implications for the Brasiliano orogeny in eastern Borborema Province Northeast Brazil. Journal of South American Earth Sciences, 100:102590. https://doi.org/10.1016/j.jsames.2020.102590
Tikoff B., Greene D. 1997. Stretching lineations in transpressional shear zones: an example from the Sierra Nevada Batholith, California. Journal of Structural Geology, 19(1):29-39. https://doi.org/10.1016/ S0191-8141(96)00056-9

Van Schmus W.R., Kozuch M., Brito Neves B.B. 2011. Precambrian history of the Zona Transversal of the Borborema Province, NE Brazil: Insights from $\mathrm{Sm} / \mathrm{Nd}$ and $\mathrm{U} / \mathrm{Pb}$ geochronology. Journal of South American Earth Sciences, 31(2-3):227-252. https://doi.org/10.1016/j. jsames.2011.02.010

Vauchez A., Neves S.P., Caby R., Corsini M., Egydio-Silva M., Arthaud M.H., Amaro V. 1995. The Borborema shear zone system, NE Brazil. Journal of South American Earth Sciences, 8(3-4):247-266. https://doi. org/10.1016/0895-9811(95)00012-5

Viegas L.G.F., Archanjo C.J., Hollanda M.H.B.M., Vauchez A. 2014. Microfabrics and zircon U-Pb (SHRIMP) chronology of mylonites from the Patos shear zone (Borborema Province, NE Brazil). Precambrian Research, 243:1-17. https://doi.org/10.1016/j.precamres.2013.12.020 